\title{
GLOBALIZATION AND SOCIAL TRANSITION
}

\author{
Gerald Schneider
}

When the Bolivian government tried to privatize water services on the recommendation of the World Bank in 1999 the citizens of Cochabamba, the country's third largest city, took their opposition to this liberalization project to the streets. These demonstrations intensified following a steep rise in water prices which had been the result of the takeover of the local water works by multinational consortium.

The occasionally violent clashes of the protestors with the Bolivian state in 1999 and 2000 came to be known as the Cochabamba Water War; they are generally seen as an ideal illustration of the social ills that economic integration can bring about. ${ }^{1}$ Two movies - Quantum of Solace, a James Bond installment, and También la lluvia (Even the Rain), a Spanish production linking these events to Latin America's colonial past - and numerous documentaries try to convince their audiences that the opening up of protected markets to international goods and capital undermines the social fabric of the developing world.

However, systematic examinations of the globalization-civil conflict nexus provide a more nuanced picture of the domestic consequences of growing economic interdependence, be it mandated by an international organization or voluntarily introduced by the government in charge. While the growth effects of economic integration appease societies in the long term (Hegre et al. 2003; Barbieri and Reuveny 2005; Flaten and de Soysa 2012), the path that needs to be taken to reap the benefits of globalization increases social tensions and the risk of civil violence (Bussmann, et al. 2005; Bussmann and Schneider 2007; Magee and Massoud 2010). In essence, abrupt liberalization measures amount to negative economic shocks for a certain part of the society at least in the short term. This might motivate those who have lost their jobs or parts of their income, or face a high risk to be bereaved in this way, to haggle with other groups over who has to shoulder the costs of the necessary adaptation of the economy to global competition (Alesina and Drazen 1991). Such confrontations run the risk of turning violent as the losers of economic integration might calculate that the benefits of restoring the status quos through the use of force outweigh the anticipated utility of accepting the liberalization measures.

"Globalization shocks" (Nieman 2011) can in this vein increase the risk of civil war, although a sudden closing of the economy might be more harmful than an abrupt liberalization (Wiesehomeier, et al. 2009). As foreign economic liberalization played a key role in the policy prescriptions advocated by the International Monetary Fund (IMF) under the banner of the "Washington Consensus," such shocks could also be traced back to the austerity measures 
governments of indebted countries agreed to impose in exchange for IMF loans. While Hartzell, et al. (2010) believe, based on a systematic evaluation, the structural adjustment programs advocated by the IMF to ignite the flames of war, a replication by Midtgaard, et al. (2012) does not find such an effect.

This chapter introduces current debates on the globalization-civil conflict nexus. I argue that the main limitation that besets these studies is the exclusive focus on already escalated interactions between competing social and political groups. As governments and international actors can appease the possible opponents of liberalizing measures through foreign aid and welfare policies or quell the protests through increased repression, the political economy literature of civil conflict needs to consider the possible substitutability of political violence through other political instruments that allow the disadvantaged to voice their protest. The literature should also become aware of the possibility that the winners and losers of foreign economic liberalization coincide more or less with ethnic or other preexisting fault lines within a society. Empirical studies should thus consider how different aspects of diversity dampen or fuel the effects that globalization has (Wiesehomeier, et al. 2009). Addressing new theoretical and empirical findings on the resource curse (Garfinkel et al. 2008; Ross 2012), the chapter concludes with a discussion of the effects that the globalization of commodity markets has on the risk of internal conflict.

\section{Theoretical perspectives on the nexus between internal peace and globalization}

International agencies such as the IMF and, to a lesser extent, the World Bank have since the debt crisis of the 1980s advanced the recommendation that highly indebted, stagnating economies should embrace deep liberalization as a growth strategy and, by extension, as a means to stabilize their economies and societies. The Washington Consensus enshrined this optimism for some time as the official development doctrine, and some empirical studies supported the liberal hope that there is a causal pathway going from globalization and liberalization over development to peace. Sachs and Warner (1995) for instance demonstrate for the first part of this argument that economically open countries have grown faster in the post-World War II era. Åslund, et al. (1996: 289) conclude, based on an analysis of the post-communist world, that "radically reforming countries perform better" (p. 289), that "people want faster reforms" (p. 227) and that government stability in these so-called "big bang countries" is larger than in economies which have followed a gradualist reform strategy. The World Bank report by Collier et al. (2003:134) added the second twist to this stabilization expectation by arguing, and providing some empirical evidence in support of it, that "growth diversifies an economy, and this reduces the risk of conflict in addition to the direct contribution of growth to risk reduction." This argument resembles the adaptation of commercial liberalism to intrastate relations by Hegre, et al. (2003), embracing the hope that trade renders states more peaceful.

The opportunity costs arguments, that the World Bank report as well as Collier and Hoeffler $(1998,2004)$ popularized, based on the path-breaking research by Haavelmo (1954) and others, has also been implicitly advanced in the reasoning on the globalization-internal conflict nexus. Globalized countries should, in other words, face a lower risk of internal violent conflict because the welfare spurred through foreign economic liberalization and other policy reforms renders the organization of a military campaign, or the participation in it, less attractive than engaging into "normal" economic activities. Nieman (2011: 282) provides a shorthand version of this cost-benefit logic, arguing that "globalization decreases internal violence by raising opportunity costs of joining an insurgency group." It is, however, not immediately clear why we should either expect positive income shocks to decrease the risk of conflict, as the standard liberal argument outlined above suggests, or to increase it in an equivalent way as a sudden reduction of aggregate 
welfare, as Nieman's (2011) initial theoretical argument implies. ${ }^{2}$ The political economy literature on how economic shocks affect the chance for peace is more developed. It was recently quite clearly established that radical food price increases - which might result from a liberalization effort like the abolishment of subsidies - are a precursor to political violence (Arezki and Brückner 2011), while the rise of export commodity prices has the opposite impact (Brückner and Ciccone 2010; see also Miguel et al. 2004; Ciccone 2011). These findings indicate that we need to specify much more clearly who the winners and losers of economic integration are and that the separation of the positive welfare effect of liberalization measures from the redistributive impact they have for certain parts of the society is critical.

Simple opportunity cost arguments that do not consider the contradictory trends of proglobalization policies are, in other words, an insufficient foundation for any attempt to build a theoretical bridge between economic integration and internal conflict. ${ }^{3}$ For a sounder analysis it is necessary to draw upon political economy models that take the redistributive effect of changing levels of economic integration into account. Standard theoretical frameworks developed in this literature suggest that the domestic debate over the extent of globalization follows a cleavage between industrial sectors (Ricardo-Viner model) or factors of production (Heckscher-Ohlin model). The former model suggests that the import-competing sector within an economy is most vehemently opposed to economic integration. As liberalization measures such as a reduction in tariffs (or corresponding steps in the informal sector like a success in an anti-corruption program) reduce the opportunity costs of political violence for agents attached to the protected sector in the short run, we should expect an increasing risk of civil war especially in the planning stage of the liberalization program. Of course, if capital or workers could immediately move towards the winning sector, such an opposition would be superfluous. However, some of the capital invested in the import-competing industry is sticky and can only be geared to the winning exportcompeting industry after some time. The same is the case with some of the skills workers acquired for jobs in the protected industries. Any globalization-induced social transformation has, in this political economy perspective, almost inevitably redistributive effects. Note that even ardent proponents of globalization such as Fischer (2003:10) contend along these lines that "globalization creates losers as well as winners in the short run."

The Heckscher-Ohlin model, which is more general in comparison to the Ricardo-Viner model through its abandonment of the assumption of sector specificity, suggests some division over the foreign economic policy of a country in the long run. The approach expects the abundant factor within an economy to favor free trade and the scarce factor to oppose such liberalizing measures. The Heckscher-Ohlin model suggests, in other words, a class struggle over trade policy making, with the opposition to globalization coming from labor in the developed and from capital in the developing world. While new developments in trade theory account for the heterogeneity of firms within a particular sector (e.g. Melitz 2003), we can expect the workers in the less productive firms to be particularly opposed to liberalizing measures. Be that as it may, all modern political economy models of trade agree that opening up the economy to increased trade will remain controversial domestically despite the aggregate welfare gains a society can expect.

Adjustments costs within an economy also accrue if a country tries to attract foreign direct investment through capital account liberalization. Although such a policy reform might spur general economic growth through the increase in the capital stock of a country, not all parts of the society profit equally from it. Arestis and Caner (2010:321) show for instance that "capital account openness is associated with a lower income share of the poorest $20 \%$ of the population." Unsurprisingly, in light of such findings, one of the fiercest critics of this form of globalization, Nobel Prize awardee Joseph Stiglitz (2000, 2004), maintains that, in particular, the short-term 
investment inflows that might follow such pro-globalization measures destabilize societies. In his view, "capital flows are markedly procyclical, exacerbating economic fluctuations, when they do not actually cause them” (Stiglitz 2000: 1079). Moreover, the liberalized economy quickly loses the trust of the international financial community during a crisis, falling victim to speculative attacks and the radical outflow of the short-term investments. The odds that a country experiencing a currency crisis will also endure a sovereign debt crisis have been around 2.5, according to the global estimation by Schneider and Genovese (2012) for the period between 1950 and 2007. The almost inevitable need to cut back the budget following the outbreak of financial crisis has gone hand in hand with an increasing incidence of strikes in the OECD area even before the collapse of the Lehman Brothers (Wassmann 2012).

In light of these discussions even former proponents of the peace-through-liberalization thesis, including the World Bank, have moved away from their early optimism on the effects of globalization. As the organization states in its 2011 World Development Report, "[E]conomic globalization exposes states to external economic stresses ranging from international corruption to resource shortages" (World Bank 2011: 278). Some globalization critics have gone beyond that. Chua (2003) maintains in a broadly received treatise that globalization ignites the flames of ethnic hatred. This expectation is based on the assumption that some minorities possess an economically dominant position and that economic integration together with democratization fosters income inequalities along these ethnic cleavages. Glaeser (2005) develops a formal model of this argument suggesting that the incentive to spread hatred against such a globalizationprofiteering minority grows because populists using this rhetoric have more to gain from asking for a redistribution of the integration bonanza. Only the study by Olzak (2011) has moved the empirical evidence in favor of such claims beyond the anecdotal illustrations by Chua (2003) and the descriptive evidence of Glaeser (2005). Distinguishing ethnic from non-ethnic wars and relying on fractionalization as a diversity measure, Olzak (2011: 21, italics suppressed) shows empirically that diversity intensifies the violence stemming from economic integration: "economic globalization actually raises the rate of fatalities from ethnic civil war." Note, however, that Wiesehomeier, et al. (2009) consider different forms of diversity and show that the interaction of both fractionalization and polarization with liberalization reduces the risk of civil war.

The globalization skepticism that prevails in the developed world especially since the beginning of the financial crisis should nevertheless not distract from the cumulative evidence to be presented below that economically integrated countries are less risk prone because of the positive welfare effects that the integration of an economy into world markets brings about in the long run. The social and political troubles that we should expect based on the political economy literature are more likely to occur in the short- and medium-term when a society decides to alter its foreign economic policies, be it through increased trade or capital account openness. While the profiteers of a closed economy lose a large share of income following trade liberalization, the bursting of a bubble that a capital account liberalization might have created often results in periods of economic stagnation through the sudden outflow of capital. I will discuss in the following section how the empirical literature deals with the liberal hope originally adopted from the literature on interstate war that trade and other economic interactions are major sources of peace.

\section{Mainly supportive: empirical tests of the liberal thesis}

The studies of the early 2000s have largely found support for the thesis advocated by commercial liberalism that economic globalization lowers the risk of intrastate conflict. Hegre et al. (2003) showed that globalization in the form of trade openness pacifies states internally. Barbieri and Reuveny (2005) confirm this result and also show that foreign direct and foreign portfolio 
investment reduces the risk of conflict presence, while the impact of these concepts on the more frequently used conflict onset-outcome variable is less convincing. ${ }^{4}$ De Soysa and Fjelde (2010) indirectly support this relationship in a study on the so-called Capitalist Peace according to which both economic freedom and trade appeases societies. ${ }^{5}$

However, these studies only consider the level of economic integration and not its growth, as the double conjecture of the redistributive thesis suggests. Bussmann, et al. (2005) as well as Bussmann and Schneider (2007) support in their attempts to account for the redistributive variant of commercial liberalism the optimistic expectation of the peace-through-globalization school of thought that trade openness renders countries more peaceful. Further, while positive changes in the level of trade increase - in line with their modification of the liberal hope - the risk of conflict, the FDI inflow relative to the GDP decreases rather than increases the risk of domestic conflict (Bussmann and Schneider 2007). This latter finding is in contrast to the Stiglitzian fear that capital account liberalization destabilizes countries, but it might also be due to the difficulties to truly separate long- and short-term investments from each other. The distributive interpretation of the liberal thesis suggests, as indicated above, that only the latter form of economic integration potentially uproots a society.

As the conflict-inducing effect of positive changes in trade openness is largely due to globalization shocks, Bussmann and Schneider (2007: 94) nevertheless maintain that "policy makers and the international community" should consider the disruptive power of globalization discontent "in their attempts to reform the domestic economy by way of global economic integration." Distinguishing between trade openness and open foreign economic policies as measured by Sachs and Warner (1995), Magee and Massoud (2010) show that the conflictfostering impact of liberalization sets in just before a country truly integrates itself into the world markets. This finding is in line with Bussmann and Schneider's (2007) theory, "but only if the true beginning of the liberalization process is long before the year in which the country first satisfies the Sachs [and] Warner conditions for being considered open" (Magee and Massoud 2010: 66) Future tests need to consider the extent to which anti-globalization protests are anticipatory and how long they are able to postpone the implementation of liberalizing policy measures.

A similar argument stressing the disruptive effects of IMF-mandated liberalizations is made by Hartzell, et al. (2010). They find a tangible impact of the entry into structural adjustment programs and argue that "the IMF-guided process of liberalization generates new losers at a rate with which a state with weakening powers is incapable of contending" (p. 353). Midtgaard, et al. (2012), however, show that slight changes in the research design lead to completely different findings and that IMF programs might at least reduce the risk of lower-scale conflicts.

More recent studies have examined the impact of globalization on various other forms of internal violence than civil war. Dreher, et al. (2012), for instance, demonstrate in a study on the impact of globalization on human rights that the respect for physical integrity rights significantly grows with political, social, and economic forms of globalization, whereas the analogous relationship with empowerment rights is less robust. Similarly, Flaten and de Soysa (2012: 639) show that a "country that increases its globalization score by a standard deviation increases respect for human rights by roughly $40 \%$ of a standard deviation of the physical integrity rights score."These important results are in line with Harff's (2003) pioneering study on the correlates of genocides.According to her calculations, countries with low levels of economic interdependence face a much higher risk of a "state failure" escalating into genocide than economically integrated countries. Yet, although these results address important debates in the public scene and are bolstered by the usage of sophisticated econometric modeling techniques, they lack a sound theoretical mechanism as the decision to engage in a civil conflict does not necessarily coincide with the calculations a government makes when deciding on the level of repression. 


\section{Challenges and perspectives}

The lack of solid support for some of the key propositions on the linkage between trade and internal conflict begs the question of how the literature could be improved. I will contend below that the main challenges to commercial liberalism are of a theoretical rather than methodological nature despite the important observation by Martin et al. (2008) as well as Magee and Massoud (2010) that most studies suffer under severe shortcomings. The most notable challenge arises from what is known as "endogeneity bias" and thus the tendency to treat globalization as an exogenous factor and as a social and political outcome for which the attributes of a country and the international system at a given point of time are responsible. Although we may be able to solve this problem through the application of advanced econometric techniques, its presence surely signals the need for further theoretical reasoning on the issue.

\section{Substitutability of protest instruments}

One of the greatest challenges in laying down solid analytical foundations for any model of political violence is the need to avoid the narrowing down of the potential choices that individuals and groups can make to a dichotomy between war and peace. As we know through Hirschman (1970), protest takes many forms, with violence surely being the most extreme and costly one. Hence, the real or potential losers of liberalization measures will most likely express globalization discontent in parliamentary debates or, if they are badly represented politically, take their grievances to the street if they have the possibility of relying on these protest instruments. We should thus observe that at least the incidence of strikes goes up as a consequence of plans to open markets for foreign competition in countries in which trade unions are not well represented through a powerful ally in the national parliament. However, growing labor unrest will not necessarily translate into an increased risk of political violence since the possibility of voicing the concerns against planned measures in a peaceful movement might curtail the legitimacy of those who consider the use of armed force to influence the foreign policy stance of their country. If we fail to consider this multitude of options, we underestimate how severe the redistributive effect of liberalization is at least in the short term. The recognition that taking up arms is only one - and a rare - possibility to fight against globalization measures implies that the political economy literature should develop theoretical models that consider the institutional context in which such decisions are made. This means for the empirical study of civil war that we need to take the interaction of foreign economic liberalization and contextual factors into account.

\section{Globalization and the resource curse}

The strength of the association between liberalization and conflict might not only be mediated by the availability of other protest options, but also depend on the increase in trade of a particular commodity.Although the study of the globalization-domestic conflict nexus lacks a disaggregated analysis as the one Dorussen (2006) produced for the study of the interstate wars, the newer literature on the resource curse suggests the importance of differentiating between particular export and import goods. The formal work by Garfinkel, et al. (2008) implies, for instance, that the international market price of a domestically contested and exportable resource is of utmost importance. Increased demand for oil and thus growing trade can increase conflict because the resultant higher international price increases the rents of the resource owners and simultaneously the costs that are invested in obtaining access to the resource as well as in banning those attempts to gain the possession: 
Although for importers of oil and other natural resources opening up the economy brings the regular benefits of trade and reductions in conflict, for exporters of the same resources opening the economy to trade can very well induce increased conflict costs that more than offset the familiar gains from trade

(Garfinkel et al. 2008: 307)

Recent work supports these qualifications of the resource curse thesis. Ross (2012) observes for instance in a masterful study that the risk of civil conflict grows with the per capita oil income, with this effect being especially pronounced for poor countries and thus those societies in which the welfare obtained through the exportable commodity crucially matters. The political economy of drug cultivation in Colombia exhibits, according to Angrist and Kugler (2008), similar patterns.

As the influential article by Mehlum, et al. (2006) shows, resource ownership plays a crucial mediating role. Countries in which the rule of law is under-developed are particularly "grabberfriendly" and thus open for the detrimental influence of kleptocratic rulers and other nonproductive profiteers of the resource bonanza. As this "distributional coalition" drives out any entrepreneurial spirit from the economy, high income inequality and low growth are the almost necessary consequences of a resource boom, increasing, in turn, the risk of civil war considerably. Snyder (2006) and many others conversely point out that joint institutions of extraction lower the risk of conflict. However, resources erode the quality of political institutions over time (Ross 2012) so that the sharing of resource rents might be a temporary phenomenon.

The dependence of the resource rents on the developments of world markets renders state ownership highly problematic in case of negative price shocks. While a positive income shock weakens other economic sectors possibly through the appreciation of the local currency, as standard theories of the "Dutch disease" claim, falling commodity income makes it difficult for the central government to quell popular dissatisfaction through redistributive measures. Yet, there is, to my knowledge, no convincing study of how the volatility of the commodity prices influences the protest potential as resource ownership plays a crucial role here. Negative oil price shocks for instance will increase the protest potential not only because of the income losses for those dependent on this sector. These shocks also limit the ability of the government to quell the protests through social policies or increased investments in internal security and repression. As Ross (2012: 57) notes, governments are particularly exposed to such shocks as they typically receive a larger, but more variable, part of the oil profits than foreign contractors. There is a considerable literature that shows how welfare states reduce the risk of war (Taydas and Peksen 2012) or the risk of terrorism (Krieger and Meierrieks 2010). Similarly, increasing foreign aid reduces, according to most studies, the onset and incidence of civil war, while the sudden reduction of these flows has the opposite effect (Nielsen et al. 2011). To conclude, as much as the literature has to deal with the multiple options of the possible globalization losers to voice their anger, as much needs the literature to deal with the options of the governments in dealing with the potential protest.

\section{Globalization across ethnic and social cleavages}

One of the shortcomings of the current studies on the globalization-peace interrelationship is additionally the lack of attention given to the diverging impact that liberalization might have across varying groups of a society. The Heckscher-Ohlin model suggests that skilled workers will profit especially from an opening up of the country to foreign competition. If educational opportunities are unequally distributed among the relevant social or ethnic groups within a 
society, globalization discontent might arise particularly among the unskilled segments of a society that has embraced economic liberalization as a development strategy. Additionally, if the abundant factor is concentrated in one particular group, anti-globalization hatred might be leveled against these profiteers of liberalization measures. The aforementioned studies by Chua (2003) and Olzak (2011) pay attention to the differential impact that globalization might have across different ethnic groups. Their reasoning is, however, not solidly based on a political economy model that allows us to differentiate between the income and redistributive effects that liberalization has even for the less privileged group. In other words, the former impact might dwarf the latter one to such an extent that increased globalization remains relatively uncontroversial. In order to study the diverging effect of liberalization in diverse countries in a systematic fashion, we need to move below the country-year framework in the study of the globalization-conflict nexus. The surveys used by Østby (2008) or, in the case of geographic segregation of groups within a country, GIS data might be possible data resources for the future analysis of the impact that trade and capital account liberalization might have on the internal stability of states.

\section{Conclusion}

The nexus between economic forms of globalization and civil war is less straightforward than the initial empirical studies on the topic suggested (Hegre, et al. 2003). This complexity is a consequence of the redistributive effect of foreign economic liberalization. As the author of this survey has argued in collaboration with Margit Bussmann and others, plans to increase the level of economic integration will meet the resistance of those who, at least in the short run, risk to lose income or even their jobs to competitors elsewhere. There is indeed some evidence that liberalization (Bussmann and Schneider 2007; Bussmann, et al. 2005) or the plans to integrate an economy further into world markets (Magee and Massoud 2010) increases the risk of internal violence, while globalized economies have a lower risk of violence due to the positive welfare effects of trade and long-term direct investment.

The double hypothesis of the redistributive interpretation of the globalization-conflict nexus faces nevertheless considerable theoretical and empirical hurdles. Conflict researchers can only overcome these analytical challenges through the development of refined theoretical arguments that consider the multiple possibilities to voice anti-globalization anger in some societies and to quell the opposition through compensatory payments to the losing group or through increased repression.

The biggest challenge to the liberal hope would, however, be a return to protectionism just 100 years after the abrupt end of the first globalization wave. The consequent closure of the leading economies in the 1920s was crucial for the ideological polarization that resulted in the rise of fascism and the outbreak of World War II (Esteban and Schneider 2008). Since the shock of extreme economic closure exceeds the redistributive effect of liberalization measures by far, impoverishing large parts of the society, it is not surprising that the risk of genocide and other extreme social ills is particularly pronounced in extremely autarchic regimes (Harff 2003). In order to understand these dangers, we need to move beyond a simplistic protectionismglobalization dichotomy and to provide precise causal mechanisms of how specific reforms of foreign economic policies affect the internal stability of states.

\section{Acknowledgments}

I would like to thank the German Research Foundation for research support and my co-authors with whom I have worked on the topic covered in this article, especially Margit Bussmann and Nina Wiesehomeier, as well as the editors of this volume and Friederike-Luise Kelle for 
comments. Although I discuss some of the issues raised here more broadly in Schneider (2014), this is a standalone chapter. The usual caveat that I am solely responsible for the content of this chapter applies.

\section{Notes}

1 The conflict is not listed as a civil war in the Uppsala/PRIO Armed Conflict Data set.

2 Nieman (2011:269) expects "globalization shocks" to increase the risk of civil war "because globalization has winners and losers," a hypothesis that the empirical analysis disconfirms.

3 Fearon (2008) and Schneider (2010) offer more general critiques of the usage of the opportunity cost argument in the civil war literature.

4 Barbieri and Reuveny (2005) also consider internet usage as a form of economic globalization.

5 Other researchers working on the Capitalist Peace do not necessarily control for the impact of facets of globalization on internal conflict (cf. Mousseau 2012). This is all the more astonishing as trade and capital account openness are key aspects of capitalism (Schneider and Gleditsch 2010).

\section{References}

Alesina,A. and Drazen,A. (1991) Why are Stabilizations Delayed? American Economic Review, 81(5): 1170-1188. Angrist, J. D. and Kugler, A. D. (2008) Rural Windfall or a New Resource Curse? Coca, Income, and Civil Conflict in Colombia, Review of Economics and Statistics, 90(2): 191-215.Arestis, P. and Caner, A. (2010) Capital Account Liberalization and Poverty: How Close is the Link? Cambridge Journal of Economics, 34(2): 295-323.

Arezki, R. and Brückner, M. (2011) Food Prices, Conflict, and Democratic Change, International Monetary Fund Working Paper 11/26, Washington, DC.

Åslund, A., Boone, P., and Johnson, S. (1996) How to Stabilize: Lessons from Post-Communist Countries, Brookings Papers on Economic Activity, 1: 217-313.

Barbieri, K. and Reuveny, R. (2005) Economic Globalization and Civil War, Journal of Politics, 67(4): 1228-1247. Brückner, M. and Ciccone, A. (2010) International Commodity Prices, Growth and the Outbreak of Civil War in Sub-Saharan Africa, Economic Journal, 120(544): 519-534.

Bussmann, M. and Schneider, G. (2007) When Globalization Discontent Turns Violent: Foreign Economic Liberalization and Internal War, International Studies Quarterly, 51(1): 79-97.

Bussmann, M., Schneider, G., and Wiesehomeier, N. (2005) Foreign Economic Liberalization and Peace: The Case of Sub-Saharan Africa, European Journal of International Relations, 11(4): 551-579.

Chua, A. (2003) World On Fire: How Exporting Free Market Democracy Breeds Ethnic Hatred and Global Instability, New York: Anchor Books.

Ciccone, A. (2011) Economic Shocks and Civil Conflict: A Comment, American Economic Journal: Applied Economics, 3(4): 215-227.

Collier, P. and Hoeffler, A. (1998) On Economic Causes of Civil War, Oxford Economic Papers, 50(4): 563-573.

Collier, P. and Hoeffler,A. (2004) Greed and Grievance in Civil War, Oxford Economic Papers, 56(4): 563-595.

Collier, P., Elliott, E., Hegre, H., Reynal-Querol, M., and Sambanis, N. (2003) Breaking the Conflict Trap: Civil War and Development Policy, Washington, DC: World Bank.

de Soysa, I. and Fjelde, H. (2010) Is the Hidden Hand an Iron Fist? Capitalism and Civil Peace, 1970-2005, Journal of Peace Research, 47(3): 273-285.

Dorussen, H. (2006) Heterogeneous Trade Interests and Conflict:WhatYou Trade Matters, Journal of Conflict Resolution, 50(1): 87-107.

Dreher, A., Gassebner, M., and Siemers, L.-H. R. (2012) Globalization, Economic Freedom, and Human Rights, Journal of Conflict Resolution, 56(3): 516-546.

Esteban, J. and Schneider, G. (2008) Polarization and Conflict: Theoretical and Empirical Issues, Journal of Peace Research, 45(2): 131-141.

Fearon, J. D. (2008) Economic Development, Insurgency, and Civil War, in E. Helpman (ed.) Institutions and Economic Performance, Cambridge, MA: Harvard University Press, pp. 292-328.

Fischer, S. (2003) Globalization and its Challenges, American Economic Review, 93(2): 1-30.

Flaten, R. D. and de Soysa, I. (2012) Globalization and PoliticalViolence, 1970-2008, International Interactions, 38(5): 622-646. 
Garfinkel, M. R., Skaperdas, S., and Syropoulos, C. (2008) Globalization and Domestic Conflict, Journal of International Economics, 76(2): 296-308.

Glaeser, E. L. (2005) The Political Economy of Hatred, Quarterly Journal of Economics, 120(1): 45-86.

Haavelmo, T. (1954) A Study in the Theory of Economic Evolution, Amsterdam: North-Holland.

Harff, B. (2003) No Lessons Learned from the Holocaust? Assessing Risks of Genocide and Political Mass Murder Since 1955, American Political Science Review, 97(1): 57-73.

Hartzell, C. A., Hoddie, M., and Bauer, M. (2010) Economic Liberalization via IMF Structural Adjustment: Sowing the Seeds of Civil War? International Organization, 64(2): 339-356.

Hegre, H., Gissinger, R., and Gleditsch, N. P. (2003) Globalization and Internal Conflict, in G. Schneider, K. Barbieri, and N. P. Gleditsch (eds.) Globalization and Armed Conflict, Lanham, MD: Rowman and Littlefield, pp. 251-275.

Hirschman, A. O. (1970) Exit, Voice, and Loyalty: Responses to Decline in Firms, Organizations, and States, Cambridge, MA: Harvard University Press.

Krieger, T. and Meierrieks, D. (2010) Terrorism in the Worlds of Welfare Capitalism, Journal of Conflict Resolution, 54(6): 902-939.

Magee, C. S. P. and Massoud,T. G. (2010) Openness and Internal Conflict, Journal of Peace Research, 48(1):59-72.

Martin, P., Mayer, T., and Thoenig, M. (2008) Civil War and International Trade, Journal of the European Economic Association, 6(3): 541-550.

Mehlum, H., Moene, K., and Torvik, R. (2006) Institutions and The Resource Curse, Economic Journal, 116(1): 1-20.

Melitz, M. (2003) The Impact of Trade on Intra-Industry Reallocations and Aggregate Industry Productivity, Econometrica, 71(6): 1695-1725.

Midtgaard, T. M., Vadlamannati, K. C., and de Soysa, I. (2012) Bad Medicine? Intervention by the International Monetary Fund and the Risk of Civil War, 1970-2009, unpublished working paper, Norwegian University of Science and Technology.

Miguel, E., Satyanath, S., and Sergenti, E. (2004) Economic Shocks and Civil Conflict: An Instrumental Variables Approach, Journal of Political Economy, 112(4): 725-753.

Mousseau, M. (2012) Capitalist Development and Civil War, International Studies Quarterly, 56(3): 470-483.

Nielsen, R. A., Findley, M. G., Davis, Z. S., Candland, T., and Nielson, D. L. (2011) Foreign Aid Shocks as a Cause of Violent Armed Conflict, American Journal of Political Science, 55(2): 219-232.

Nieman, M. D. (2011) Shocks and Turbulence: Globalization and the Occurrence of Civil War, International Interactions, 37(3): 263-292.

Olzak, S. (2011) Does Globalization Breed Ethnic Discontent? Journal of Conflict Resolution, 55(1): 3-32.

Østby, G. (2008) Polarization, Horizontal Inequalities and Civil Conflict, Journal of Peace Research, 45(2): $143-162$.

Ross, M. L. (2012) The Oil Curse. How Petroleum Wealth Shapes the Development of Nations, Princeton, NJ: Princeton University Press.

Sachs, J. D. and Warner, A. (1995) Economic Reform and the Process of Global Integration, Brookings Papers on Economic Activity 1: 1-118.

Schneider, G. (2010) Economics and Conflict, in R.A. Denemark (ed.) The International Studies Encyclopedia, Malden, MA/Oxford:Wiley-Blackwell, pp. 1284-1300.

Schneider, G. (2014) Peace through Globalization and Capitalism? Prospects of Two Liberal Propositions, Journal of Peace Research, 51(1) doi: 10.1177/0022343313497739 (ahead of print).

Schneider, G. and Genovese, F. (2012) Smoke with Fire: Financial Crises, Institutional Reform, and the Future of EU Democracy, unpublished working paper, University of Konstanz.

Schneider, G. and Gleditsch, N. P. (2010) "The Capitalist Peace”: The Origins and Prospects of a Liberal Idea, International Interactions, 36(2): 107-114.

Snyder, R. (2006) Does Lootable Wealth Breed Disorder? A Political Economy of Extraction Framework, Comparative Political Studies, 39(8): 943-968.

Stiglitz, J. E. (2000) Capital Market Liberalization, Economic Growth and Instability, World Development 28(6): 1075-1086.

Stiglitz, J E. (2004) Capital-Market Liberalization, Globalization, and the IM, Oxford Review of Economic Policy, 20(1): 57-71.

Taydas, Z. and Peksen, D. (2012) Can States Buy Peace? Social Welfare Spending and Civil Conflicts, Journal of Peace Research, 49(2): 273-287.

Wassmann, P. (2012) Fiscal Consolidation, Fiscal Pressure and Strikes: An Empirical Assessment, unpublished MA thesis, University of Konstanz. 
Wiesehomeier, N., Schneider, G., and Braun, C.-S. (2009) Die Vereinbarkeit des Unvereinbaren? Wirtschaft und Identität als gemeinsame Bürgerkriegsursachen, Politische Vierteljahresschrift Sonderheft 43: 445-470.

World Bank (2011) World Development Report 2011: Conflict, Security, and Development, Washington, DC:The World Bank. 